\title{
DEMYSTIFYING EMPLOYMENT Authorization AND Prosecutorial DISCRETION IN IMMIGRATION CASES
}

\author{
SHOBA SIVAPRASAD WADHIA*
}

On November 20, 2014, President Barack Obama announced a series of immigration programs aimed to reform the immigration system. Deferred Action for Parents of Americans or Lawful Permanent Residents (DAPA) and extended Deferred Action for Childhood Arrivals (DACA) represent two such programs announced by the President. Both programs extend deferred action (one form of prosecutorial discretion) to qualifying individuals. Deferred action has been part of the immigration system for more than 50 years, and has been named explicitly by Congress, federal courts, and the agencies responsible for administering immigration laws. Additionally, regulations list deferred action as one basis for work authorization. The President's deferred action programs offered room for a bealthy debate about immigration law and policy. The debate was intensified by a lawsuit brought by the state of Texas and 25 other states challenging the deferred action programs, and a subsequent judicial opinion enjoining these programs. Much of the tension has centered on the ability for a deferred action grantee to obtain ancillary benefits like employment authorization or lanful presence. This conflict has enabled great distortion about the limits and benefits of prosecutorial discretion in immigration law. In this Article, I seek to clarify the relationship between prosecutorial discretion and employment authorization and describe the bistorical precedent for allowing qualifying noncitizens to apply for work authorization based on a prosecutorial discretion grant. I also examine the policy questions that are raised by the current legal framework and policy for work authorization. My methodology for this Article is to review the primary and secondary sources of law for prosecutorial discretion and employment authorization; analyze a related data set of more than 200,000 work authorization applications processed by the United States Citizenship and Immigration Services retrieved through the Freedom of Information Act; and begin a policy discussion on the benefits of enabling prosecutorial discretion beneficiaries to be authorized to work in the United States. This Article is the first to analyze the law and policy of employment authorization and prosecutorial discretion and builds naturally from my body of work developed on the role of immigration prosecutorial discretion generally, and deferred action in particular.

I. INTRODUCTION 2

II. UNDERSTANDING THE LAW AND RELATIONSHIP BETWEEN EMPLOYMENT AUTHORIZATION AND PROSECUTORIAL DISCRETION .....................................
A. Deferred Action 5

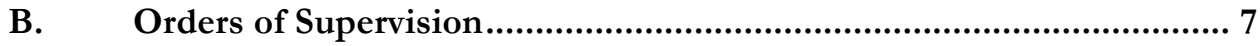
C. Parole .10

III. EXAMINING DATA ON EMPLOYMENT AUTHORIZATION APPLICATIONS Processed Pursuant to a Grant of Prosecutorial Discretion ........ 11
A. Number of Employment Authorization Applications Processed....... 11
B. Employment Authorization Application Decisions by Gender. 12 
C. Employment Authorization Applications and Decisions by

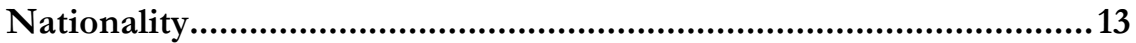

D. Employment Authorization Applications and Outcomes by

Processing Center ........................................................................14

E. Employment Authorization Applications and Outcomes by Category

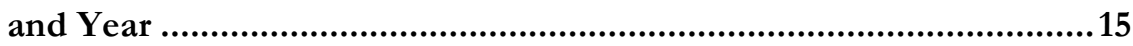

F. Employment Authorization Applications and Approvals Based on a

Deferred Action Grant....................................................................15

G. Employment Authorization Applications and Approvals Based on an

Order of Supervision Grant ................................................................17

H. Employment Authorization Applications and Approvals Based on a

Parole Grant ...........................................................................17

IV. EMPLOYMENT AUTHORIZATION FOR PROSECUTORIAL DisCRETION

GRANTEES: A GOOD POLICY?...................................................................18

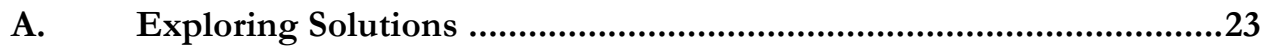

B. Political Challenges to Employment Authorization Applications .....24

C. Operational Challenges to Employment Authorization Applications25

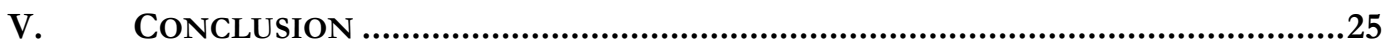

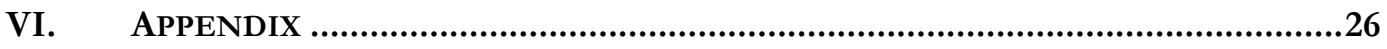

\section{INTRODUCTION}

This Article clarifies the relationship between prosecutorial discretion and employment authorization ${ }^{1}$ and describes the historical precedent for allowing qualifying noncitizens to apply for work authorization based on a prosecutorial discretion grant. It also examines the policy questions that are raised by the current legal framework and procedure for work authorization. The methodology for this Article is to review the primary and secondary sources of law for prosecutorial discretion and work authorization; analyze data sets of select work authorization applications processed by U.S. Citizenship and Immigration Services

\footnotetext{
* Samuel Weiss Faculty Scholar, Clinical Professor of Law and Director at Penn State Law. I am very grateful to Michael A. Olivas, Stephen H. Legomsky, Steve Yale-Loehr, Lenni Benson and Peter Margulies for providing me with feedback on an earlier draft. I send my appreciation to the editorial staff of the CJRL and also to Doyinsola Aribo ('14), Vienna Vasquez ('16), and Lauren Holzer ('16) for their outstanding research assistance and to Penn State Law for supporting my scholarship

1 Throughout this Article, the terms "employment authorization," "work authorization," and "work permit" will be used interchangeably.
} 
("USCIS") retrieved through the Freedom of Information Act ("FOIA"); and begin a policy discussion on the benefits of enabling prosecutorial discretion beneficiaries to be authorized to work in the United States. This Article will analyze the law and policy of work permits and prosecutorial discretion and builds naturally from a body of work developed on the role of immigration prosecutorial discretion generally, and deferred action in particular. ${ }^{2}$

The exercise of prosecutorial discretion is an important feature in the immigration system. It requires each Department of Homeland Security ("DHS") component to make decisions about whether a person legally eligible for immigration enforcement should still be allowed to reside in the United States on a temporary basis. Prosecutorial discretion recognizes that in a universe of limited resources, an individual or group may qualify as a "low priority" for enforcement and/or bear the kinds of qualities that are unsuitable for removal. ${ }^{3}$ This discretion functions as a form of protection from removal but provides no formal legal status. ${ }^{4}$ There are several kinds of prosecutorial discretion in immigration law, but only a few of these forms offer the possibility of work authorization. For the vast majority of individuals living in the United States without a legal status but protected through a form of prosecutorial discretion, there is no independent basis for work.

On November 20, 2014, President Barack Obama announced a catalogue of immigration programs aimed to administratively reform the system through a combination of rulemaking and policy guidance. Three of those policy changes include Deferred Action for Parents of Americans and Lawful Permanent Residents (DAPA), an extension of Deferred Action for Childhood Arrivals (DACA), and parole for certain entrepreneurs. ${ }^{5}$ These programs extend deferred action or parole, which are both forms of prosecutorial discretion, to qualifying individuals, providing the possibility for work authorization. Parole has been part of the immigration system since at least the early 1900 s and has been codified in the immigration statute designed by Congress and regulations. ${ }^{6}$ Deferred action has been part of the immigration system for more than fifty years, and is featured in the immigration statute, federal court decisions, regulations, and agency

\footnotetext{
2 Shoba Sivaprasad Wadhia, Beyond Deportation: The Role of Prosecutorial Discretion in IMMigRATION CASES (2015); Shoba Sivaprasad Wadhia, Immigration Remarks for the 10th Annual Wiley A. Branton Symposium, 57 How. L.J. 931, 933 (2014) (discussing examples of prosecutorial discretion); Shoba Sivaprasad Wadhia, My Great FOLA Adventure and Discoveries of Deferred Action Cases at ICE, 27 GEO. IMMIGR. L.J. 345, 345-385 (2013); Shoba Sivaprasad Wadhia, In Defense of DACA, Deferred Action, and the DREAM Act, 91 TEXAS L. REV. 59 (2013); Shoba Sivaprasad Wadhia, Sharing Secrets: Examining Deferred Action and Transparency in Immigration Law, 10 U. N.H. L. REV. 1 (2012); Shoba Sivaprasad Wadhia, The Role of Prosecutorial Discretion in Immigration Law, 9 ConN. PUB. INT. L.J. 243 (2010). 3 See, e.g., Memorandum from Jeh Charles Johnson, Sec'y, U.S. Dep't of Homeland Sec., to Thomas S. Winkowski, Acting Dir., U.S. Immigration and Customs Enforcement et al. on Policies for the Apprehension, Detention and Removal of Undocumented Immigrants (Nov. 20, 2014), http://www.dhs.gov/sites/default/files/publications/14_1120_memo_prosecutorial_discretion.pdf [hereinafter Jeh Charles Johnson Memorandum]; Memorandum from John Morton on Exercising Prosecutorial Discretion Consistent with the Civil Immigration Enforcement Priorities of the Agency for the Apprehension, Detention, and Removal of Aliens, U.S. Immigration and Customs Enforcement, 3 (June 17, 2011), http://www.ice.gov/doclib/securecommunities/pdf/prosecutorial-discretion-memo.pdf [hereinafter John Morton Memorandum].

${ }^{4}$ See e.g., Memorandum from Karl Thompson, Principal Deputy Assistant Attorney Gen. to the Sec'y of Homeland Sec. and the Counsel to the President on The Dep't of Homeland Sec. Authority to Prioritize Removal of Certain Aliens Unlawfully Present in the United States and to Defer Removal of Others (Nov. 19, 2014), http://www.justice.gov/sites/default/files/olc/opinions/attachments/2014/11/20/2014-11-19-auth-prioritizeremoval.pdf_[hereinafter Karl Thompson Memorandum] ("Deferred action does not confer any lawful immigration status, nor does it provide a path to obtaining permanent residence or citizenship.”); Letter from Scholars and Teachers of Immigration Law on the Executive Actions Announced by the President on November 20, 2014 (Mar. 13, 2015), https://pennstatelaw.psu.edu/_file/LAWPROFLTRHANENFINAL.pdf [hereinafter Letter from Scholars and Teachers] (describing the difference between lawful presence and lawful status in the immigration context). ${ }^{5}$ U.S. Citizenship and Immigration Services, Executive Actions on Immigration, http://www.uscis.gov/immigrationaction (last visited Nov. 10, 2015).

6 See, e.g., 8 U.S.C. $\ 1182(\mathrm{~d})(5)(A)(2013) ; 8$ C.F.R. $\ 212.5$ (2011).
} 
memoranda. ${ }^{7}$ Qualifying grantees of deferred action or parole may qualify for additional benefits, like lawful presence and work authorization, both of which are detailed in a later section of this Article. ${ }^{8}$

Much of the tension around the President's deferred action programs has centered on the ability for a possibly large class of individuals to receive work authorization on the basis of a deferred action grant. The politics of deferred action and work authorization peaked when Texas and 25 other states challenged the legality of these deferred action programs. ${ }^{9}$ Consequently, U.S. District Court Judge Andrew Hanen for the Southern District of Texas placed the extended DACA and DAPA programs on hold. ${ }^{10}$ The deferred action programs continued to be criticized by the plaintiffs, judges, and amicus curiae briefs. ${ }^{11}$ Meanwhile, the Department of Justice has maintained that eligibility to apply for work authorization flows from deferred action and pre-dates the announcements made by President Obama in 2014. ${ }^{12}$

\section{UNDERSTANDING THE LAW AND RELATIONSHIP BETWEEN EMPLOYMENT AUTHORIZATION AND PROSECUTORIAL DISCRETION}

A review of the immigration statute and regulations that govern work authorization for immigrant populations generally and prosecutorial discretion beneficiaries in particular reveals that standard administrative law principles apply: statutory delegation, deference to agency interpretations when statutes are ambiguous, notice and comment rulemaking, and so on. Congress has delegated to DHS the legal authority for issuing work authorization to noncitizens; the Immigration and Nationality Act ("INA"), as provided in Title 8 U.S.C. $\int 1103(\mathrm{a})(1)$ vests in the Secretary of Homeland Security the power to administer and enforce the INA and related laws, ${ }^{13}$ and provides DHS with the authority to establish regulations and policies to carry

\footnotetext{
78 U.S.C. S 1103(a)(1) (2015) ("charging the Secretary of Homeland Security with the administration and enforcement of this Act and all other laws relating to the immigration and naturalization of aliens"); Arizona v. United States, $132 \mathrm{~S}$. Ct. 2492, 2499 (2012) (stating that "[a] principal feature of the removal system is the broad discretion exercised by immigration officials ... Federal officials, as an initial matter, must decide whether it makes sense to pursue removal at all.”). See Employment Authorization to Aliens in the United States, 46 Fed. Reg. 25079-03, 25081 (May 5, 1981). See also 8 C.F.R. \274a.12(c)(14) (2015) (“An alien who has been granted deferred action, an act of administrative convenience to the government which gives some cases lower priority, if the alien establishes an economic necessity for employment").

8 See infra Section II.

${ }_{9}^{9}$ United States v. Texas, SCOTUSblog (last visited Jan. 26, 2016), http://www.scotusblog.com/case-files/cases/unitedstates-v-texas/.

10 Suzanne Gamboa, Legal Experts: Ruling Blocking Immigration Action 'Deeply Flawed', NBC NEws, Mar. 13, 2015 , http://www.nbcnews.com/news/latino/experts-texas-judges-immigration-action-ruling-deeply-flawed-n322751.

11 See Plaintiffs' Opposition to Motion for Stay Pending Appeal at 12, Texas v. United States, 787 F.3d 733 (5th Cir. 2015) (No. 15-40238) (internal quotations omitted), http://images.politico.com/global/2015/03/23/txoppstayca5.pdf (stating that "DAPA rewrites the immigration laws in multiple ways. First, it confers benefits the Executive is not authorized to confer. In particular, the Executive cannot unilaterally grant lawful presence, work permits, and a host of other benefits to $40 \%$ of the unauthorized aliens in the U.S. Such unlawful action cannot be papered over as enforcement discretion.").

12 See, e.g., Brief for the Appellants at 46, Texas v. United States 787 F.3d 733 (5th Cir. 2015) (No. 15-40238) 2015 WL 1611821 at $* 46$ (internal citations omitted) (indicating that the "district court also erred in concluding that the 2014 Guidance establishes a new right to work lawfully in the United States. Aliens accorded deferred action may be authorized to work if they apply for employment authorization, pay the necessary processing fees, and establish an economic necessity for employment. But that is the result of a 1981 regulation that makes all aliens accorded deferred action eligible to apply for work authorization. It is that long established regulation, not the 2014 Guidance that permits aliens accorded deferred action to apply for employment authorization. That regulation went through an extended process of notice and public comment before its adoption, in conformity with the APA.").

138 U.S.C. \1103(a)(1) (2015) ("charging the Secretary of Homeland Security with the administration and enforcement of this Act and all other laws relating to the immigration and naturalization of aliens").
} 
out the provisions of the INA. ${ }^{14}$ Moreover, 8 U.S.C. $\$ 1324 \mathrm{a}(\mathrm{h})(3)$ defines an "unauthorized alien" for employment purposes as a person who is neither an LPR nor "authorized to be ...employed by [the INA] or by the Attorney General [now Secretary of Homeland Security]. ${ }^{15}$ This language, "or by the Secretary of Homeland Security," has served as at least one statutory basis for DHS to name people who could work, and Congress has placed no cap on the number of work permits that may be issued.

\section{A. Deferred Action}

Formerly called "non-priority" status, deferred action is one form of prosecutorial discretion that was revealed publicly in the $1970 \mathrm{~s}$ in connection with the immigration case of former Beatle, John Lennon. ${ }^{16}$ Deferred action functions as a form of non-enforcement because it defers or places a hold on the deportation of the individual. ${ }^{17}$ DHS can process and grant deferred action to an individual at any stage of the immigration process, including but not limited to the point of arrest, before detention, before a removal proceeding, and after a removal order has been entered. ${ }^{18}$ While the history is rich, deferred action remains opaque for attorneys unfamiliar with how to make a request, as there is no current form, fee, or public information about how to apply except for the DACA program. ${ }^{19}$ One internal document, obtained through FOIA in 2013, instructs that deferred action requests to USCIS be made in writing and signed by the

148 U.S.C. $\int 1324 \mathrm{a}(\mathrm{h})(3)(2015)$.

${ }^{15}$ For example, in a rule pertaining to the eligibility for spouses of H-1B workers to be authorized to work, the government relied on 8 U.S.C. $\$ 1324(\mathrm{~h})(3)$, stating that " $\mathrm{t}]$ he authority of the Secretary of Homeland Security (Secretary) for this regulatory amendment can be found in section 102 of the Homeland Security Act of 2002, Public Law 107-296, 116 Stat. 2135, 6 U.S.C. 112, and section 103(a) of the Immigration and Nationality Act (INA), 8 U.S.C. 1103(a), which authorize the Secretary to administer and enforce the immigration and nationality laws. In addition, section $274 \mathrm{~A}(\mathrm{~h})(3)(\mathrm{B})$ of the INA, 8 U.S.C. 1324a(h)(3)(B), recognizes the Secretary's authority to extend employment to noncitizens in the United States." Employment Authorization for Certain H-4 Dependent Spouses, 80 Fed. Reg. 10284 (Feb. 25, 2015) (to be codified at 8 C.F.R 214, 274(a). Some critics have argued that all $\$ 1324 a(h)(3)$ does is authorize DHS to grant work permits to those noncitizens for whom the statute independently provides permission to work. See, e.g., Jan Ting, Center for Immigration Studies, President Obama's “Deferred Action” Program for Illegal Aliens is Plainly Unconstitutional, 13 (2014) (citing John C. Eastman, President Obama's "Flexible” View of the Law: The DREAM Act as Case Study, Roll CALL Aug. 28, 2014, http://www.rollcall.com/news/Obamas-FlexibleView-of-the-Law-The-DREAM-Act-as-Case-Study-235892-1.html). But such a reading of the statute would render the term "or the Attorney General" and several statutory provisions that preclude work permits for specific classes of noncitizens superfluous. See Hearing Before the U.S. H. Comm. on the Judiciary, 114th Cong. (2015) (statement of Stephen H. Legomsky,John S. Lehmann Univ. Professor, Washington Univ. Sch. of Law)

https://lofgren.house.gov/uploadedfiles/legomsky_testimony.pdf.

${ }^{16}$ Leon Wildes, The Nonpriority Program of the Immigration and Naturalization Service Goes Public: The Litigative Use of the Freedom of Request Act, 14 SAn Diego L. ReV. 42, 44-47 (1976); Shoba Sivaprasad WADHia, Beyond Deportation: The Role of Prosecutorial Discretion in ImMigration CASES 14 (2015).

17 See, e.g., Karl Thompson Memorandum, supra note 4 (stating that "[g]rants of deferred action under the proposed programs would, rather, represent DHS's decision not to seek an alien's removal for a prescribed period of time.”); see also Shoba Sivaprasad Wadhia, The History of Prosecutorial Discretion in Immigration Law, 64 AM. U. L. REV. 1285 (2015). 18 See, e.g., Jeh Charles Johnson Memorandum, supra note 3; Memorandum from Doris Meissner, Comm'r, Immigration and Naturalization Serv., on Exercising Prosecutorial Discretion (Nov. 17, 2000), http://www.legalactioncenter.org/sites/default/files/docs/lac/Meissner-2000-memo.pdf; SHOBA SIVAPRASAD

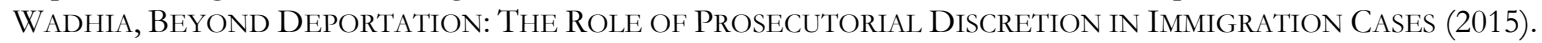
19 See, e.g., Shoba Sivaprasad Wadhia, Standard Operating Procedure for Deferred Action (non-DACA), SELECTED WORKS OF SHOBA SIVAPRASAD WADHIA (2015), http://works.bepress.com/shoba_wadhia/36/; see generally SHOBA SIVAPRASAD WAdHia, Beyond Deportation: The Role of ProseCutorial DisCretion in IMMigration CASES, ch. 4, 7, 8 (2015). 
requestor, along with an explanation for why deferred action is being sought, supporting documentation, proof of identity and nationality, among other requirements. ${ }^{20}$

As stated previously, deferred action is not a legal status, but it is a precious form of protection because it enables a person to reside in the United States without fear of immediate deportation. ${ }^{21}$ Deferred action has been explicitly named in the immigration statute ${ }^{22}$ and federal court decisions, ${ }^{23}$ including the U.S. Supreme Court. ${ }^{24}$ Importantly, the regulations developed by former Immigration and Naturalization Service ("INS") and inherited by DHS specifically list deferred action as a basis for work authorization. ${ }^{25}$

The legal authority behind granting work authorization to deferred action beneficiaries was eloquently expressed by Professor Stephen H. Legomsky in his testimony before the U.S. House of Representatives Committee on the Judiciary: "In continuing to grant work permits to deferred action recipients who can demonstrate economic necessity, USCIS is exercising a discretionary power expressly granted by Congress, incorporated into the formal regulations, and in active use for more than three decades." 26 A similar analysis was expressed in the Department of Justice's Office of Legal Counsel (OLC) opinion: "Under longstanding regulations and policy guidance promulgated pursuant to statutory authority in the INA, deferred action recipients may receive two additional benefits.... relying on DHS's statutory authority to authorize certain aliens to work in the United States, DHS regulations permit recipients of deferred action to apply for work authorization if they can demonstrate an 'economic necessity for employment."'27

For some deferred action programs, DHS has also provided some instructions to applicants about their eligibility to apply for employment authorization pursuant to a deferred action grant. ${ }^{28}$ Likewise, the "Frequently Asked Questions" document ("FAQ") created by USCIS for DACA explicitly rests the authority for work authorization on the regulatory framework outlined above, namely Title 8 of the Code of Federal Regulations. The FAQ states in part:

${ }^{20}$ Letter from Shoba Sivaprasad Wadhia, Clinical Professor and Director of Center for Immigrants' Rights, to USCIS in re FOIA request (May 24, 2013), https://pennstatelaw.psu.edu/_file/Immigrants/FOIA_May_2013.pdf. A more elaborate description of deferred action can be found in previous work and will not be repeated here. See, e.g., Shoba Sivaprasad Wadhia, Sharing Secrets: Examining Deferred Action and Transparency in Immigration Law, 10 U. N.H. L. REv. 1 (2012); Shoba Sivaprasad Wadhia, Beyond Deportation: The Role of Prosecutorial Discretion in IMMIGRATION CASES, 55-57 (2015).

21 See, e.g., Karl Thompson Memorandum, supra note 4; Letter from Immigration Law Teachers and Scholars to President Obama (Sept. 3, 2014), https://pennstatelaw.psu.edu/_file/Law-Professor-Letter.pdf; Letter from Immigration Law Teachers and Scholars (Nov. 25, 2014), https://pennstatelaw.psu.edu/sites/default/files/documents/pdfs/Immigrants/executive-action-law-prof-letter.pdf. 22 See, e.g., Deportable Aliens, 8 U.S.C. \1227(d)(4).

23 See generally Soon Bok Yoon v. INS, 538 F.2d 1211, 1213 (5th Cir. 1976); see also Vergel v. INS, 536 F.2d 755 (8th Cir. 1976); David v. INS, 548 F.2d 219 (8th Cir. 1977); Nicholas v. INS, 590 F.2d 802 (9th Cir. 1979).

${ }^{24}$ See, e.g., Reno v. Am.-Arab Anti-Discrimination Comm., 525 U.S. 471, 483-4 (1999) ("At each stage the Executive has discretion to abandon the endeavor, and at the time IIRIRA was enacted the INS had been engaging in a regular practice (which had come to be known as 'deferred action') of exercising that discretion for humanitarian reasons or simply for its own convenience.").

258 C.F.R. $\$ 274 a .12$ (c)(14) (2015) (stating that "[a]n alien who has been granted deferred action, an act of administrative convenience to the government which gives some cases lower priority, if the alien establishes an economic necessity for employment"). See also Employment Authorization to Aliens in the U.S., 46 Fed. Reg. 25079-03, 25081 (May 5, 1981).

${ }^{26}$ Hearing, supra note 15 (Statement of Stephen H. Legomsky, John S. Lehmann Univ. Professor, Washington Univ. Sch. of Law).

${ }^{27}$ Karl Thompson Memorandum, supra note 4.

28 See, e.g., Press Release, U.S. Citizen and Immigration Services, USCIS Announces Interim Relief for Foreign Students Adversely Impacted By Hurricane Katrina (Nov. 25, 2005),

http://www.uscis.gov/sites/default/files/files/pressrelease/F1Student_11_25_05_PR.pdf ("Katrina-impacted foreign academic students not covered by the Notice and their dependents (F-2 visa holders) may request deferred action and apply for employment authorization based on economic necessity.”). 
Q4: If my removal is deferred under the consideration of DACA, am I eligible for employment authorization?

A4: Yes. Under existing regulations, if your case is deferred, you may obtain employment authorization from USCIS provided you can demonstrate an economic necessity for employment. ${ }^{29}$

Beyond the possibility of work authorization, a grant of deferred action enables a person have a "lawful presence" in the United States for the period during which her deportation is deferred. ${ }^{30}$ The distinction between a formal "legal status" and treating one as "lawfully present" is an important one, and has been recently misunderstood by critics. ${ }^{31}$ Lawful presence preserves the ability for a person to depart the United States and seek admission in the future without triggering one of the "unlawful presence" bars. ${ }^{32}$ Even though deferred action while in effect can cure a person's presence, the period in deferred action does not cure previous periods of unlawful presence. ${ }^{33}$ Like with all forms of prosecutorial discretion, deferred action does not confer a formal legal status and is revocable at any time. ${ }^{34}$ By contrast, "legal status" provides legal security, a substantive right or benefit, and a possible means for permanent status in the United States. ${ }^{35}$ As explained by the Department of Justice's OLC opinion:

This difference [between lawful presence and legal status] is not, in our view, insignificant. But neither does it fundamentally transform deferred action into something other than an exercise of enforcement discretion: As we have previously noted, deferred action confers no lawful immigration status, provides no path to lawful permanent residence or citizenship, and is revocable at any time in the agency's discretion. ${ }^{36}$

\section{B. Orders of Supervision}

An "order of supervision" ("OSUP") is another form of prosecutorial discretion in immigration law. ${ }^{37}$ Unlike deferred action, which can be granted or processed at any stage of immigration enforcement, an

298 C.F.R. \274a.12(c)(14) (2015); U.S. Citizenship \& Immigration Services, Frequently Asked Questions, http://www.uscis.gov/humanitarian/consideration-deferred-action-childhood-arrivals-process/frequently-askedquestions (last visited Feb. 10, 2016).

${ }^{30}$ Memorandum from Donald Neufeld, Acting Associate Dir., U.S. Immigration and Customs Enforcement et al., on Consolidation of Guidance Concerning Unlawful Presence for Purposes of Sections 212(a)(9)(B)(i) and 212(a)(9)(C)(i)(I) of the Act to Field Leadership, 42 (May 6, 2009),

http://www.uscis.gov/sites/default/files/USCIS/Laws/Memoranda/Static_Files_Memoranda/2009/revision_redesign _AFM.PDF [hereinafter Donald Neufeld Memorandum].

31 See, e.g., Anil Kalhan, Deferred Action, Supervised Enforcement Discretion, and the Rule of Law Basis for Executive Action on Immigration, 63 UCLA L. REV. DisCOURSE 58 (2015), http://papers.ssrn.com/sol3/papers.cfm?abstract_id=2596049 (discussing that critics of the President often conflate legal status and lawful presence); Letter from Scholars and Teachers, supra note 4 at 4 (describing the difference between lawful presence and status).

32 See, e.g., 8 U.S.C SS 1182(a)(9)(B)(i)(I)-(II) (outlining that individuals without lawful presence will be denied reentry into the country).

33 See, e.g., Donald Neufeld Memorandum, supra note 30, at 4.

34 Jeh Charles Johnson Memorandum, supra note 3.

35 See, e.g., Letter from Scholars and Teachers, supra note 4, at 4 (indicating Judge Hanen overlooked the difference between lawful presence and legal status).

${ }^{36}$ Karl Thompson Memorandum, supra note 4.

378 U.S.C. \$1231(a)(3) (2006) (“Supervision after 90-day period”); See also Memorandum from Julie L. Myers, Assistant Secretary on Prosecutorial and Custody Discretion to All Field Office Directors and All Special Agents in Charge (Nov. 7, 2007), https://www.ice.gov/doclib/foia/prosecutorial-discretion/custody-pd.pdf; U.S. IMMIGRATION AND CUSTOMS 
order of supervision may be processed after the government orders removal. ${ }^{38}$ An OSUP may be issued by DHS after a person has been ordered removed through a truncated procedure like reinstatement, ${ }^{39}$ administrative removal, ${ }^{40}$ or after a court procedure that ends with a removal order by a judge in the Department of Justice. ${ }^{41}$ A spectrum of noncitizens may receive an order of supervision. Individuals granted withholding of removal ${ }^{42}$ or protection under the U.N. Convention Against Torture ("CAT") 43 and protected in the United States, if in custody, may be released on an order of supervision. Likewise, a person held in custody but unable to be removed because of a country's refusal to issue a travel document may be released on an order of supervision. ${ }^{44}$ In some of these situations, release on an order of supervision may be required in order to comply with due process. ${ }^{45}$ Outside of these contexts, Immigration and Customs Enforcement's ("ICE") choice to issue an order of supervision to individuals residing in the United States with a removal order is an act of prosecutorial discretion. ${ }^{46}$

The immigration statute explicitly permits DHS to provide work authorization to noncitizens who have already been ordered removed. ${ }^{47}$ Furthermore, the regulations developed by former INS and inherited by current DHS specifically list orders of supervision as a basis for work authorization. The regulation reads:

An alien against whom a final order of deportation or removal exists and who is released on an order of supervision under the authority contained in section 241(a)(3) of the Act may be granted employment authorization in the discretion of the district director only if the alien cannot be removed due to the refusal of all countries designated by the alien or under section 241 of the Act to receive the alien, or because the removal of the alien is otherwise impracticable or contrary to the public interest. Additional factors which may be considered by the district director in adjudicating the application for employment authorization include, but are not limited to, the following:

(i) The existence of economic necessity to be employed;

ENFORCEMENT, TOOL KIT FOR ProseCUTORS (2011), https://www.ice.gov/doclib/about/offices/osltc/pdf/tool-kitfor-prosecutors.pdf; Jeh Charles Johnson Memorandum, supra note 3; Letter from Law Professors to President Barack Obama, 2-3, (Sept. 3, 2014), https://pennstatelaw.psu.edu/_file/Law-Professor-Letter.pdf.

38 8 U.S.C. $\int 1231$ (a)(3) ("Supervision after 90-day period").

398 U.S.C. $\int 1231$ (a)(5) ("Reinstatement of removal orders against aliens illegally reentering").

408 U.S.C. \$1228(b) ("Removal of aliens who are not permanent residents"). See generally Shoba Sivaprasad Wadhia, The Rise of Speed Deportation and the Role of Discretion, 5 COLUM. J. RACE \& L. 1, 7-10 (2014) (presenting a background on speed deportation removal procedures).

418 U.S.C. \1229; 8 C.F.R. \1240.41; 8 C.F.R. \1241.1(describing when an order of removal becomes final once a person has gone through removal proceedings before an immigration judge).

42 See 8 U.S.C. $\int 1231$ (b)(3) (2006) ("Supervision after 90-day period. If the alien does not leave or is not removed within the removal period, the alien, pending removal, shall be subject to supervision under regulations prescribed by the Attorney General...”).

43 See 8 C.F.R. \ 208.18 (2009), for provisions of U.S. regulations relating to the Convention Against Torture.

44 See 8 C.F.R. S 241.13 (a), (h); See also Letter from Catrina M. Pavlik-Keenan, FOIA Officer, U.S. Immigration and Customs Enforcement, to author (May 1, 2015), http://works.bepress.com/shoba_wadhia/33/

45 See e.g., Zadvydas v. Davis, 533 U.S. 678, 679 (2001) (noting that " $[\mathrm{t}]$ he post-removal-period detention statute, read in light of the Constitution's demands, implicitly limits an alien's detention to a period reasonably necessary to bring about that alien's removal from the United States, and does not permit indefinite detention...A statute permitting indefinite detention would raise serious constitutional questions. Freedom from imprisonment lies at the heart of the liberty protected by the Due Process Clause.").

468 U.S.C. $\int 1231$ (a)(3) (2006) (“Supervision after 90-day period”).

478 U.S.C. $\int 1231$ (a)(7) (permitting the Attorney General under certain narrow circumstances to grant work authorization to aliens who have received final orders of removal but cannot be removed). 
(ii) The existence of a dependent spouse and/or children in the United States who rely on the alien for support; and

(iii) The anticipated length of time before the alien can be removed from the United States. ${ }^{48}$

Beyond the primary sources of law, ICE policy documents detail the procedures for orders of supervision. ${ }^{49}$ While an order of supervision grant can protect a person from removal and is anchored with the possibility of work authorization, this form of discretion is not as precious as deferred action because it does not provide for a period of lawful presence and, in many cases, requires the beneficiary to report to a local immigration enforcement office. ${ }^{50}$ The conditions may also include geographic limitations on where the individual can reside while under supervision and restrictions on the individual's freedom, such as an electronic monitoring bracelet. ${ }^{51}$ ICE data provides that an alien may be released on an order of supervision according to the following guidelines:

a. Process is typically handled by ERO [Enforcement Removal Operations]

b. Alien has been held in detention and has final order of removal:

i. In process of acquiring travel documents, or

ii. Granted deferred action (for example, for humanitarian reasons), or

iii. Travel documents are not forthcoming in the reasonably foreseeable

future so alien cannot be held in detention any longer, based on post

order custody review (POCR). ${ }^{52}$

ICE's data also indicates that the Form 220-B used to process orders of supervision may typically contain the following information regarding conditions:

- Reporting frequency

- Requirement to provide details on activities and associations and any other information ICE considers appropriate

- Travel restrictions - notification for travel outside specified boundaries for more than 48 hours

- Compliance with conditions of parole or probation for any criminal charge..$^{33}$

Internal guidance from ICE also reveals that noncitizens may be required to pay a bond as a condition of their release on an order of supervision. ${ }^{54}$ Individuals who fail to comply with an order of supervision can be taken back into custody. ${ }^{55}$ In all of these ways, a release on an order of supervision is more limiting than a grant of deferred action.

48 C.F.R. $\$ 274 a .12(c)(18)(2015)$.

${ }^{49}$ ICE provided the author with 107 pages of information pertaining to the agency's internal policies and procedures relating to orders of supervision. See generally Letter from Catrina M. Pavlik-Keenan, FOIA Officer, U.S. Immigration and Customs Enforcement, to author (May 1, 2015), http://works.bepress.com/shoba_wadhia/33/ (describing alternatives to detention and electronic monitoring guidelines for released aliens).

50 See, e.g., Id.; see also Geoffrey Hereen, The Status of Nonstatus, 64 AM. U. L. REv. 1115, 1116 (2015).

${ }^{51}$ Letter from Catrina M. Pavlik-Keenan, supra note 49. See generally Memorandum by Gary Mead to Field Office Directors on Orders of Supervision, Immigration and Customs Enforcement (Sep. 28, 2006), http://www.ice.gov/doclib/foia/dro_policy_memos/ordersofsupervisionsep282006.pdf (outlining ICE's own policy and procedure for processing orders of supervision in 2006); see also Geoffrey Hereen, The Status of Nonstatus, 64 AM. U. L. REV. 1115, 1146-48 (2015) (describing how an order of supervision perpetuates the "nonstatus" of thousands of persons living in the United States).

${ }_{52}$ Letter from Catrina M. Pavlik-Keenan, supra note 49.

${ }^{53} I d$.

${ }^{54} I d$.

558 C.F.R. $\$ 241.4(1)(2015)$. 


\section{Parole}

Parole is a long-established concept in immigration law and was first codified by Congress in $1952 .{ }^{56}$ The immigration statute defines parole:

(A) The Attorney General may, ... in his discretion parole into the United States temporarily under such conditions as he may prescribe only on a case-by-case basis for urgent humanitarian reasons or significant public benefit any alien applying for admission to the United States, but such parole of such alien shall not be regarded as an admission ...

(B) The Attorney General may not parole into the United States an alien who is a refugee unless the Attorney General determines that compelling reasons in the public interest with respect to that particular alien require that the alien be paroled into the United States rather than be admitted as a refugee under section 1157 of this title..$^{57}$

The regulations elaborate the bases for parole. ${ }^{58}$ Furthermore, federal regulations provide that an alien paroled into the United States temporarily for emergency reasons or reasons may apply for employment authorization. ${ }^{59}$ Finally, DHS has published internal guidelines and public memoranda on different forms of parole, all of which emanate from the above-stated statutory and regulatory framework. ${ }^{60}$ Parole in place, or "PIP," is another tool available to the spouses, parents and children of military members seeking to adjust status in the United States. ${ }^{61}$ In November 2014, and as part of his executive actions on immigration, President Barack Obama advised USCIS to create a parole program aimed at entrepreneurs:

... $[\mathrm{T}] \mathrm{o}$ inventors, researchers, and founders of start-up enterprises who may not yet qualify for a national interest waiver, but who have been awarded substantial U.S. investor financing or otherwise hold the promise of innovation and job creation through the development of new technologies or the pursuit of cutting edge research. Parole in this type of circumstance would allow these individuals to temporarily pursue research

568 U.S.C. $\$ 1182(\mathrm{~d})(5)(\mathrm{A})(2013)$.

578 U.S.C. $\$ 1182(\mathrm{~d})(5)(\mathrm{A})(2013)$.

588 C.F.R. $\$ 212.5$ (2011).

598 C.F.R. \$274a.12(c)(11)(2015) (describing categories of aliens who must apply for employment authorization and providing that " $\mathrm{a}] \mathrm{n}$ alien paroled into the United States temporarily for emergency reasons or reasons deemed strictly in the public interest pursuant to $\$ 212.5$ of this chapter.").

${ }^{60}$ In response to FOIA request from the author about policies relating to parole, USCIS produced 77 pages of information, including the standard operating procedure for "parole in place." Memorandum from Shoba Sivaprasad Wadhia on USCIS Documents on Parole to Interested Parties, (Jan. 28, 2015), http://works.bepress.com/cgi/viewcontent.cgi?article=1060\&context=shoba_wadhia; see generally SHOBA SIVAPRASAD Wadhia, Beyond Deportation, The Role of Prosecutorial Discretion in ImMigration Cases, 27 (2015) (providing a history of parole in the immigration context); see also David A. Martin, A Defense of Immigration-Enforcement Discretion: The Legal and Policy Flaws in Kris Kobach's Latest Crusade, 122 YALE L.J. ONLINE 167 (2012), http://yalelawjournal.org/forum/a-defense-of-immigration-enforcement-discretion-the-legal-and-policy-flaws-in-kriskobachs-latest-crusade (describing how parole has operated historically).

${ }^{61}$ Policy Memorandum, U.S. Citizenship and Immigration Services, Parole of Spouses, Children and Parents of Active Duty Members of the U.S. Armed Forces, the Selected Reserve of the Ready Reserve, and Former Members of the U.S. Armed Forced or Selected Reserve of the Ready Reserve and the Effect of Parole on Inadmissibility under Immigration and Nationality Act $\$ 212(\mathrm{a})(6)$ (A)(i) (Nov. 15, 2013),

http://www.uscis.gov/sites/default/files/USCIS/Laws/Memoranda/2013/2013-1115_Parole_in_Place_Memo_.pdf. 
and development of promising new ideas and businesses in the United

States, rather than abroad. 62

Like with those who are granted deferred action, an individual granted parole is treated as "lawfully present," ${ }^{63}$ but provides no formal legal status. ${ }^{64}$

\section{EXamining DATA ON EMPloyment AUthorization Applications Processed Pursuant to a Grant of Prosecutorial Discretion}

As the preceding discussion showed, the legal foundation for DHS to provide work authorization to certain noncitizens who otherwise lack a formal legal status is clear. A second and important question is whether the law itself has been applied. This section analyzes a data set of 233,245 work permit applications processed with receipt dates ranging from June 19, 1990 through October 20, 2014 on the following three bases: parole, deferred action and order of supervision. ${ }^{65}$

\section{A. Number of Employment Authorization Applications Processed}

In 2014, ICE data included 233,245 work authorization applications pursuant to parole, deferred action, or an order of supervision. ${ }^{66}$ Of this number, 202,619 or $87 \%$ of applications were approved. ${ }^{67}$ This data reveals the prevalent adjudication of work authorization applications based on a grant of prosecutorial discretion and the degree to which applications for employment by USCIS are pending, denied, or closed (canceled), even where the applicant has been granted relief in the form of prosecutorial discretion.

62 Infographic: President Obama Is Taking Steps To Fix Our Broken Immigration System, THE WHITE HOUSE (Nov. 20, 2014), https://www.whitehouse.gov/share/infographic-president-obama-taking-steps-fix-our-broken-immigration-system.

${ }^{63}$ Donald Neufeld Memorandum, supra note 31.

${ }^{64}$ Martin, supra note 60.

65 In response to a FOIA request, USCIS sent the author data set that covers applications with receipt dates ranging from June 19, 1990 through October 20, 2014. The letter stated in part:

"Requester seeks information about Form I-765, Application for Employment Authorization-Class Preference C11 (Parole) 8 C.F.R. 274a.12(c)(11); C14 (Deferred Action Granted) 8 C.F.R. 274a.12(c)(14); C18 (Order of Supervision) 8 C.F.R. 274a.12(c)(18) maintained by USCIS since August 1, 2013.

Each Application

1. Nationality or country of birth

2. Gender

3. Age

4. Whether the applicant has legal counsel or a Form G-28 on file

5. Time between the receipt date on an application and a decision

6. Whether the application was approved or denied

If available, include comments or written factors explaining why an application was denied or granted."

Letter from Shoba Sivaprasad Wadhia to FOIA Officer, U.S. Citizenship and Immigration Services (Sept. 24, 2014) (on file with author).

${ }^{66}$ Letter and Response from Jill A. Eggleston, FOIA Operations Dir., U.S. Citizenship and Immigration Services, to author (Dec. 30, 2014) (on file with author) [hereinafter Employment Authorization Data].

${ }^{67}$ Id. 
Table 1: Application Decisions

\begin{tabular}{|l|l|l|}
\hline Decision & \multicolumn{1}{l}{ Total } & Percentage \\
\hline Admin Closed & 1,234 & $0 \%$ \\
\hline Approved & 202,619 & $87 \%$ \\
\hline Denied & 14,073 & $6 \%$ \\
\hline Pending & 15,319 & $7 \%$ \\
\hline
\end{tabular}

\section{B. Employment Authorization Application Decisions by Gender}

In reviewing the application decisions by gender, out of the total 233,245 applications, 117,768 of the applicants approved were female, while 84,492 of the applicants approved were male. ${ }^{68}$ One possibility for this difference is that a significant portion of those seeking work authorization pursuant to a deferred action grant are women who have been granted protection under the Violence Against Women Act (VAWA) selfpetition or conditionally approved for protection as a victim of crime (U-Visa). ${ }^{69}$ Available to both men and women, the VAWA Self Petition and U-Visa are two remedies existing under the immigration law for victims. Whereas the VAWA Self-Petition is limited to certain parents, children and spouses who have suffered abuse at the hands of a United States citizen or lawful permanent resident, the U-Visa is available to victims of a wide-range of crimes and without regard to the legal status of the abuser. ${ }^{70}$ Persons who satisfy the qualifications for a VAWA Self-Petition or U-Visa during a fiscal year during which the statutory caps have already been reached are provided deferred action as a temporary form of protection. ${ }^{71}$

\footnotetext{
${ }^{68} I d$.

${ }^{69}$ When USCIS adjudicates a U-Visa or VAWA self-petition in year during which the statutory cap has already been reached, the case is conditionally approved until the following year and the applicant is placed in a deferred action status during this period. See e.g., William A. KANDEL, CONG. RESEARCH SERV., R42477, ImMigration Provisions OF THE ViOLENCE AGAINST WOMEN ACT (VAWA) (2012), www.fas.org/sgp/crs/misc/R42477.pdf ("If the I-360 petition is ultimately approved, the foreign national is granted deferred action status, a "quasi" status and administrative act that halts actions to remove the individual from the United States for a renewable period of time."); U.S. Citizenship and Immigration Services, Victims of Criminal Activity: U Nonimmigrant Status, http://www.uscis.gov/humanitarian/victimshuman-trafficking-other-crimes/victims-criminal-activity-u-nonimmigrant-status/victims-criminal-activity-unonimmigrant-status_(last visited Feb. 11, 2016) ("If the cap is reached before all U nonimmigrant petitions have been adjudicated, USCIS will create a waiting list for any eligible principal or derivative petitioners that are awaiting a final decision and a U-visa. Petitioners placed on the waiting list will be granted deferred action or parole and are eligible to apply for work authorization while waiting for additional U-visas to become available."); SHOBA SIVAPRASAD WADHIA, Beyond Deportation: The Role of Prosecutorial Discretion in IMMigration Cases, 61-62 (2015). 70 See Victims of Trafficking and Violence Protection Act of 2000, 22 U.S.C. $\$ 7105(b)(1)(B)(i)$ (2000); 8 U.S.C. SS 1154(a)(1)(A)(v)-(vii); 8 U.S.C. $\int 1101(\mathrm{a})(15)(\mathrm{U})$.

${ }^{71}$ U.S. Citizenship and Immigration Services, supra note 69; See also, Karl Thompson Memorandum, supra note 4, at 15. See also Shoba Sivaprasad Wadhia, Beyond Deportation: The Role of Prosecutorial Discretion in IMMIGRATION CASES 62 (2015), for a historical account of the types of individuals and groups who have qualified for deferred action.
} 
Table 2: Application Decisions by Gender

\begin{tabular}{|l|l|l|}
\hline Decision & Female Applicants & Male Applicants \\
\hline Admin Closed & 634 & 591 \\
\hline Approved & 117,768 & 84,492 \\
\hline Denied & 7,796 & 6,208 \\
\hline Pending & 8,018 & 7,244 \\
\hline
\end{tabular}

\section{Employment Authorization Applications and Decisions by Nationality}

In looking specifically at nationality, the largest share of work authorization applications were made by nationals of Mexico, Cuba, Guatemala, El Salvador, and Honduras. 83,189 of the applicants were Mexican; 68,556 of the applicants were Cuban; 8,078 of the applicants were Guatemalan, 6,739 of the applicants were El Salvadoran; and 6,564 of the applicants were Honduran. ${ }^{72}$ More than $74 \%$ of the total number of work authorization application processed was represented by these five nationalities. ${ }^{73}$ With the exception of Cuba, nationals from the remaining four countries resemble the largest share of the unauthorized population overall. ${ }^{74}$ Moreover, nationals from Mexico, Guatemala, Honduras, and El Salvador represent the largest number of removals by DHS. Nationals from these four countries represented 419,158 (96\%) of 438,421 removals in 2013.75 Thus, as these nationals, Mexicans in particular, appear to benefit greatly from prosecutorial discretion decisions under which work authorization is a possibility, the rate of removal is far greater and, in the big picture, presents an enforcement-heavy policy against these populations. To illustrate this point, the annual statistics maintained by DHS reveal that $69 \%$ of the total undocumented population comes from Mexico, Guatemala, El Salvador, and Honduras, while more than $90 \%$ of those deported in the same year were nationals of these same four countries. ${ }^{76}$

\footnotetext{
72 Employment Authorization Data, supra note 66.

${ }^{73} \mathrm{Id}$.

74 See Migration Policy Institute, Profile of Unauthorized Population: United States, (last visited Oct. 26, 2015), http://www.migrationpolicy.org/data/unauthorized-immigrant-population/state/US (estimates from Migration Policy Institute indicate that Mexican nationals comprise of $58 \%$ of the unauthorized population, followed by Guatemala (6\%), El Salvador $(3 \%)$ and Honduras $(2 \%))$.

75 See, e.g., JOHN F. Simanski, DePARTMENT OF HoMELAND SECURity, OFFICE OF IMMigRATION STATISTICS, ANNUAL REPORT, IMMIGRATION ENFORCEMENT ACTIONS: 2013 (Sep. 2014 ), http://www.dhs.gov/sites/default/files/publications/ois_enforcement_ar_2013.pdf.

${ }^{76} \mathrm{Id}$.
} 
Table 3: Application Decisions by Top 5 Most Represented Countries

\begin{tabular}{|c|c|c|c|c|}
\hline Country & $\begin{array}{l}\text { Admin } \\
\text { Closed }\end{array}$ & Approved & Denied & Pending \\
\hline Mexico & 272 & 71,034 & 5,284 & 6,599 \\
\hline Cuba & 282 & 64,742 & 1,222 & 2,310 \\
\hline Guatemala & 24 & 6,204 & 787 & 1,063 \\
\hline $\begin{array}{l}\text { E1 } \\
\text { Salvador }\end{array}$ & 36 & 5,035 & 724 & 944 \\
\hline Honduras & 20 & 5,100 & 543 & 901 \\
\hline
\end{tabular}

\section{Employment Authorization Applications and Outcomes by Processing Center}

Looking specifically at decisions by processing unit, the largest number of applications were processed and approved by the National Benefits Center ("MSC") and Vermont Service Center ("VSC"). ${ }^{77}$ MSC is located in Lee's Summit, Missouri, and is responsible for preparing applications for adjudication that require an interview at a USCIS Field Office. ${ }^{78}$ VSC is located in St. Albans, Vermont, and is one of USCIS' four regional service centers. ${ }^{79}$

Table 4: Application Decisions by Service Centers ${ }^{80}$

\begin{tabular}{|l|l|l|l|l|}
\hline \multicolumn{2}{|c}{$\begin{array}{l}\text { Admin } \\
\text { Service Center }\end{array}$} & \multicolumn{1}{c}{ Approved } & \multicolumn{1}{c|}{ Denied } & Pending \\
\hline CSC & 4 & 36 & 12 & 103 \\
\hline MSC & 893 & 106,101 & 7,169 & 6,512 \\
\hline NSC & 26 & 761 & 78 & 454 \\
\hline TSC & 10 & 228 & 61 & 384 \\
\hline VSC & 301 & 95,493 & 6,753 & 7,866 \\
\hline
\end{tabular}

\footnotetext{
${ }_{77}$ Employment Authorization Data, supra note 66.

${ }^{78}$ USCIS Blog Team, The National Benefits Center: What It Is and What It Does, THE BEACON: THE OfFICIAL BLOG OF THE USCIS (June 5, 2012, 3:11 PM), http://blog.uscis.gov/2012/06/national-benefits-center-what-it-is-and.html.

${ }^{79}$ USCIS Service and Office Locator, St. Albans, Vermont Service Center, U.S. CiTIZENSHIP AND IMMIGRATION SERVICES, https://www.uscis.gov (follow "Find a USCIS Office" hyperlink; then follow "Service Centers and our National Benefit Center" hyperlink; then choose "Vermont" from "Find your offices by state" section; then follow "Vermont Service Center" hyperlink).

80 See U.S. Citizenship and Immigration Services, USCIS Service and Officer Locator, https://egov.uscis.gov/crisgwi/go?action=offices.type\&OfficeLocator.office_type=SC (last visited Mar. 2, 2016) (describing the various service centers). The full name of each abbreviated service center is as follows: CSC, California Service Center; MSC, National Service Center; NSC, Nebraska Service Center; TSC, Texas Service Center; VSC, Vermont Service Center.
} 


\section{E. Employment Authorization Applications and Outcomes by Category and Year}

Within this set, 48,692 (21\%) applications were based on C18, or Order of Supervision (“OSUP”); $114,563(49 \%)$ of the applications were based on C14, or Deferred Action ("DA"); and 69,990 (30\%) applications were based on C11, or Parole. ${ }^{81}$

Table 5: Employment Authorization Document Basis

\begin{tabular}{|l|l|l|}
\hline Basis & \multicolumn{1}{l|}{ Applicants } & \multicolumn{1}{l|}{ Percentage } \\
\hline C11 (Parole) & 69,990 & $30 \%$ \\
\hline C14 (DA) & 114,563 & $49 \%$ \\
\hline C18 (OSUP) & 48,692 & $21 \%$ \\
\hline
\end{tabular}

\section{F. Employment Authorization Applications and Approvals Based on a Deferred Action Grant}

Recent and great attention has been paid to deferred action recipients who apply for work authorization on the basis of economic necessity. As described in the previous section, the statutory and regulatory basis for providing work authorization to qualifying individuals spans more than three decades and pre-dates the deferred action programs announced by President Obama in 2012 and 2014.82 From 2012 through 2014, there was a sharp increase in applications for non-DACA deferred action.

In the deferred action program, work authorization applications on this basis jumped from 4,094 in 2012 to 23,267 in 2014.83 A greater number of pending VAWA or U-visa applications for which deferred action and work authorization is available in the interim and the greater visibility of the general deferred action program by the public and attorneys in the wake of the DACA may explain this fivefold increase. After President Obama announced the DACA program, attorneys, policymakers, and community members were engaged in the legal authority for the various types of prosecutorial discretion and the legal underpinnings of DACA. ${ }^{84}$ For example, the FAQ guide that accompanied the DACA program included this question and answer about deferred action:

Q1: What is deferred action?

A1: Deferred action is a discretionary determination to defer a removal action of an individual as an act of prosecutorial discretion. For purposes of future inadmissibility based upon unlawful presence, an individual whose case has been deferred is not considered to be unlawfully present during the period in which deferred action is in effect. An individual who has received deferred action is authorized by DHS to be present in the United States, and is therefore considered by DHS to be lawfully present during the period deferred action is in

\footnotetext{
${ }^{81}$ Employment Authorization Data, supra note 66.

82 See 8 U.S.C. \$1324(a)(h)(3) (2015); 8 C.F.R. \$274a.12(c) (2015); Karl Thompson Memorandum supra note 4, at 3-7; Letter from Law Professors to President Barack Obama, 2-3, (Sept. 3, 2014), https://pennstatelaw.psu.edu/_file/LawProfessor-Letter.pdf; SHOba Sivaprasad WAdHia, BEyOnd Deportation: THE Role of ProseCuTORial DisCRETION IN IMMigRATION CASES, 55 (2015).

${ }^{83}$ Employment Authorization Data, supra note 66.

${ }^{84}$ See Crane v. Napolitano, 920 F. Supp. 2d 724, 734 (N.D. Tex. 2013) (plaintiffs challenged "the portions of the Directive and Morton Memorandum that require ICE officers to exercise prosecutorial discretion and defer action against aliens who satisfy the Directive's criteria."); see generally Brief of Amici Curiae in Support of Respondents, Crane v. Johnson, 783 F.3d 255 (5th Cir. 2015) (No. 14-10049), 2014 WL 10657554.
} 
effect. However, deferred action does not confer lawful status upon an individual, nor does it excuse any previous or subsequent periods of unlawful presence.

Under existing regulations, an individual whose case has been deferred is eligible to receive employment authorization for the period of deferred action, provided he or she can demonstrate "an economic necessity for employment." DHS can terminate or renew deferred action at any time, at the agency's discretion. ${ }^{85}$

Notably, it is presumed that the approvals contained in this data set do not include DACA recipients. ${ }^{86}$

The high rate of applications for non-DACA deferred action-based work authorization does not provide the full picture as the approval rate for deferred action based work authorization dropped between 2012 and 2014. In 2014, 23,267 applications for work authorization were requested, of which 15,476 (67\%) were granted and 7,499 (32\%) were pending. ${ }^{87}$ In 2013, 4,257 applications were made to USCIS and 3,650 $(86 \%)$ were granted and only $123(3 \%)$ were pending. ${ }^{88}$ In 2012, 3,573 (87\%) were granted and $69(2 \%)$ applications or were pending. .8

Table 6: Deferred Action Applications

\begin{tabular}{|l|l|l|l|}
\hline Year & \multicolumn{1}{l}{ Applications Received } & \multicolumn{1}{l|}{ Granted } & \multicolumn{1}{l|}{ Pending } \\
\hline $\mathbf{2 0 1 2}$ & 4,094 & 3,573 & 69 \\
\hline $\mathbf{2 0 1 3}$ & 4,257 & 3,650 & 123 \\
\hline $\mathbf{2 0 1 4}$ & 23,267 & 15,476 & 7,499 \\
\hline
\end{tabular}

The lower approval rates for deferred action in 2014 may be explained in part by the volume of applications or the fact that employment authorization applications filed in earlier years would normally be adjudicated before those applications filed in later years. Another reason for a pending or denied request may be tied to the time USCIS requires to review the new worksheet created for applicants to use to document the "economic necessity" component of the regulatory scheme that governs deferred action based work authorization. Another possibility is that USCIS is more vigilant about adjudicating work authorization applications based on deferred action in the wake of the political discourse that emerged during the Obama Administration around executive action and immigration. A final possibility is that USCIS is simply overwhelmed with applications for work authorization based on the DACA program that they are taking longer to process these applications, spending less time on these applications, or avoiding internal conflict or discussion in close cases. These theories speculate at best.

\footnotetext{
85 U.S. Citizenship \& Immigration Services, supra note 29.

86 USCIS has indicated that the data set the author received on deferred action does not include DACA based work authorization applications. Email from Cindy Holt, Government Information Specialist, FOIA/PA, to author (April 28, 2015, 2:42pm EST) (on file with author).

${ }^{87}$ Employment Authorization Data, supra note 66.

${ }^{88} I d$.

${ }^{89}$ Id.
} 


\section{G. Employment Authorization Applications and Approvals Based on an Order of Supervision Grant}

Beyond deferred action, there were a steady number of work authorization applications based on an order of supervision in $2014(10,795)$ and 2013 (10,595). ${ }^{90}$ Notably, there was a sharp drop in approvals in work authorization applications based on an order of supervision grant. Of the 10,795 people who applied for work authorization based on an order of supervision in 2014 only 6,950 (64\%) were granted and 3,402 (32\%) applications were pending. ${ }^{91}$ Compare this to 2013, where 9,466 applications were approved, 1,060 applications were denied and 26 applications were pending. ${ }^{92}$ Perhaps USCIS denied applications based on a failure to meet one of the underlying factors like economic necessity. Importantly, as the data does not subdivide the category of order of supervision, it is difficult to know whether the orders they served were granted as an exercise of prosecutorial discretion or on other bases. For example, a person can be released on an OSUP after a grant of withholding of removal under the Convention Against Torture or because the government was required to release the person on an order of supervision based on due process grounds.

\section{H. Employment Authorization Applications and Approvals Based on a Parole Grant}

With regard to parole, there was some consistency in the number of applications processed between 2012 and 2014. The number of applications in 2012 was 10,568.93 That increased in 2013 to 12,198 and then decreased again in 2014 yielding 10,264 applications. ${ }^{94}$ Like with orders of supervision, work permit applications based on parole were granted at far higher proportions in 2012 and 2013 as compared to 2014, when $7,764(76 \%)$ of the total 10,264 applications were approved..$^{95}$ Again, the possibility that applications filed in earlier years would be processed before the later ones is high. In 2014, 2,331 (23\%) applications based on a parole grant were pending. ${ }^{96}$ The following two tables provide a visual for applications for employment authorization based on deferred action, orders of supervision, and parole between 2012 and 2014.

Table 7: Basis of Employment Authorization Applications 2012-2014

\begin{tabular}{|l|l|l|l|}
\hline Year & \multicolumn{1}{|l}{ C11 (Parole) } & \multicolumn{1}{l|}{ C14 (DA) } & C18 (OSUP) \\
\hline $\mathbf{2 0 1 2}$ & 10,568 & 4,094 & 8,267 \\
\hline $\mathbf{2 0 1 3}$ & 12,198 & 4,257 & 10,595 \\
\hline $\mathbf{2 0 1 4}$ & 10,264 & 23,267 & 10,795 \\
\hline
\end{tabular}

\footnotetext{
${ }^{90}$ Employment Authorization Data, supra note 66.

${ }^{91} I d$.

${ }^{92} I d$.

${ }^{93} I d$.

${ }^{94} I d$.

95 Id.

${ }^{96} I d$.
} 
Table 8: Basis of Approved Applications 2012-2014

\begin{tabular}{|l|l|l|l|}
\hline Year & $\begin{array}{l}\text { C11 } \\
\text { (Parole) }\end{array}$ & C14 (DA) & C18 (OSUP) \\
\hline $\mathbf{2 0 1 2}$ & 10,346 & 3,573 & 7,608 \\
\hline $\mathbf{2 0 1 3}$ & 11,890 & 3,650 & 9,466 \\
\hline $\mathbf{2 0 1 4}$ & 7,764 & 15,476 & 6,950 \\
\hline
\end{tabular}

\section{Employment Authorization for Prosecutorial Discretion Grantees: A Good POLICY?}

Between March 17, 2015 and April 6, 2015, a qualitative survey to attorneys on work permits and prosecutorial discretion survey was conducted ${ }^{97}$ to three national electronic mailing lists comprised of attorneys with experience applying for work authorization pursuant to a prosecutorial discretion grant. ${ }^{98}$ Twenty-two attorneys responded to the survey and based on this set, more than 1,000 applications for work authorizations were filed on the basis of prosecutorial discretion since 2010.99 While some of the data included work authorizations filed pursuant to a pending form of relief from removal (following a grant of administrative closure from an immigration judge), the vast majority of applications were filed on the basis of a particular form of prosecutorial discretion: deferred action for childhood arrivals (DACA); deferred action (non-DACA); order of supervision; or parole. ${ }^{100}$ Most respondents indicated that they had not changed their strategy or procedure for preparing work authorization applications. ${ }^{101}$

Not surprisingly, the survey responses overwhelmingly favored a broad policy for allowing prosecutorial discretion recipients to work and raised important questions about the application of work authorization to recipients of prosecutorial discretion. Beyond the policy views on work permits and prosecutorial discretion expressed by attorneys responding to the survey are the personal stories of those who have been able to work because of a prosecutorial discretion grant. As described by Gaby Gomez, a young man who was granted work authorization pursuant to his DACA status:

DACA, though a temporary measure, paved the way for me to seize new academic and career opportunities that once felt out of reach. DACA made it possible for me to spend last summer working on social justice issues impacting the Latino community. This work motivated me to approach my

\footnotetext{
${ }^{97}$ Shoba Sivaprasad Wadhia, Survey: Work Permits and Prosecutorial Discretion (Mar. 17, 2015) (on file with author).

${ }^{98} \mathrm{Id}$. The survey included the following substantive questions:

“ 1 . Since 2010, have you applied for work authorization based on a prosecutorial discretion request with/ grant from USCIS, CBP or ICE?

2. If you answered yes to question 1, how many work authorization applications have you filed?

3. If you answered yes to question 1, on what basis did you apply for work authorization?

4. Have you been granted work authorization under a different code than the code you used to apply? Please explain.

5. How do you prepare a work authorization application based on a grant of prosecutorial discretion?

6. Have you changed your strategy in applying for work authorization pursuant to prosecutorial discretion? Has your success rate changed in the last five years? Please describe.

7. Do you have a comment that best captures your opinion on work permits and prosecutorial discretion? For example, do you think limiting work authorization to only certain forms of PD is good policy? Why or why not?"

${ }^{99} I d$.

$100 \mathrm{Id}$.

${ }^{101}$ Id.
} 
studies with renewed interest and with an impetus to steer them in the direction of public service and advocacy. I am a proud recipient of DACA. ${ }^{102}$

Carlos Martinez is another DACA recipient whose opportunity to apply for and receive work authorization based on DACA changed his life and landed him a "dream job."

Eager to get a work permit so he could begin pursuing his career, Martinez began preparing to apply for deferred action even before the forms and guidelines to apply became available. He gathered about 180 documents to prove he has been living in the U.S. for more than 20 years. By the time the federal government began accepting applications for deferred action, Martinez was ready to apply.

...The wait to finally begin pursuing his career ended in September when he received a letter in the mail notifying him that he had been approved for deferred action. A few weeks later, he received his work permit and immediately went to apply for a social security number. With a work permit and a social security number in hand, he began applying for jobs. In November, Martinez applied for the job at IBM, which he described as his "dream job." 103

Though the data analyzed in this article focuses on work authorization applications pursuant to deferred action outside of DACA, orders of supervision and parole, Gaby and Carlos's stories highlight the profound impact of working outside of the shadows even through the tenuous status of prosecutorial discretion. The economic benefits to Gaby and Carlos are similar to reports of DACA recipients across the country, as detailed in one survey of 1,157 individuals who either applied or considered applying for DACA. ${ }^{104}$ In this sample, DACA recipients reported the following economic improvements since receiving DACA:

- $\quad 66 \%$ went from unemployed to employed after receiving DACA

- $79 \%$ got what they considered to be a 'better job'

- $68 \%$ worked better hours

- $64 \%$ earned higher salary

- $41 \%$ got a job that provided health or other benefits

- $\quad 77 \%$ reported that they are now able to more consistently cover bills

- $78 \%$ are better able to contribute to monthly household expenses. ${ }^{105}$

\footnotetext{
102 National Council of La Raza, Two Years Later: Taking Stock of D ACA's Success, Huffington POST LATINO VOICES (June 19, 2015, 4:46 PM), http://www.huffingtonpost.com/national-council-of-la-raza-/two-years-later-takingst_b_5512832.html.

${ }^{103}$ Griselda Nevarez, Deferred Action Recipient Lands 'Dream Job' A Year After Program's Announcement, HuFFINGTON POsT LATINO VOICES (June 13, 2015, 5:07 PM), http://www.huffingtonpost.com/2013/06/13/deferred-action-recipientjob_n_3437530.html.

104 CAITLIN PATLER \& JORGE A. CABrera, UCLA INSTITUTE FOR RESEARCH ON LABOR AND EMPLOYMENT, FROM UndoCUMENTED TO DACAMENTED, IMPACTS OF THE DEFERRED ACTION FOR CHILDHOOD ARRIVALS (DACA) Program, THREE YeARS Following ITS ANNOUNCEMENT (June 2015), http://www.irle.ucla.edu/publications/documents/Patler_DACA_Report_061515.pdf.

${ }^{105} I d$ at 6 . Despite these benefits, DACA recipients in this same study reported having challenges with paying the $\$ 465$ application fees for DACA. Furthermore, the study's authors point out that DACA recipients remain in lower wage jobs and find it difficult to meet basic needs. $I d$ at 3 .
} 
Beyond the individual benefits work authorization can provide for a noncitizen who is otherwise unable to find work, government reports and testimonies and policy organizations have showcased the broader economic benefits of programs like deferred action. ${ }^{106}$ According to an April 2, 2015, column published by the Center for American Progress and titled: "Assessing the Economic Impacts of Granting Deferred Action through DACA and DAPA":

$[T]$ here is much to gain economically from enabling the DACA- and DAPA-eligible population to work lawfully. As DACA and DAPA recipients earn higher wages - an estimated total of $\$ 103$ billion more over the next decade- the U.S. gross domestic product, or GDP, will increase cumulatively by $\$ 230$ billion over the next 10 years. And it is not just beneficiaries of deferred action who will see wage gains: A booming economy will increase the incomes of all Americans by an estimated $\$ 124$ billion. The growth in economic activity will also create an average of 28,814 jobs per year over the next 10 years for all Americans. ${ }^{107}$

Similarly, testimony by Social Security Administration's Chief Actuary, Stephen C. Goss to the Senate Homeland Security and Governmental Affairs Committee states:

The largest effect of the executive actions for individuals who are currently undocumented or have overstayed a visa is the opportunity to pursue DACA or DAPA status and thereby gain legal work authorization. These individuals will be able to reapply for deferred action every 3 years, as long as they continue to meet the qualifications and do not pose a security threat. The additional individuals entering the formal economy and paying taxes will have positive effects on payroll tax revenue for several decades, followed by decades where these individuals will be past working ages and will receive earned benefits from Social Security. ${ }^{108}$

The economic impact of DACA or DAPA (or legislation to undo these programs) has also been reported by the Congressional Budget Office (CBO) and the staff of the Joint Committee on Taxation (JCT). In response to one related appropriations bill that would have dismantled the deferred action programs announced by President Obama in 2014:

JCT expects that the largest effect of [this bill] would be decreased reporting of employment income by people who would be legally allowed to work because of the deferred action programs under current law but

106 Financial Implications for the Social Security Trust Funds of the President's Executive Actions on Immigration, Announced November 20, 2014: Testimony to the S. Comm. on Homeland Sec. and Governmental Affairs 114th Cong. (2015) (statement of Stephen C. Goss, Chief Actuary, Social Security Administration), www.hsgac.senate.gov/download/?id=de43c123-ca0c-4554-a4c0e1c5a70f99e7; see also Hearing, supra note 15 (statement of Stephen H. Legomsky, John S. Lehmann Univ. Professor, Washington Univ. Sch. of Law); see generally Roberto G. Gonzales \& Veronica Terriquez, How DACA is Impacting the Lives of Those Who are Now DACAmented, NATIONAL UNDACAMENTED RESEARCH PROJECT, (American Immigration Council) Aug. 15, 2013, http://www.immigrationpolicy.org/just-facts/how-daca-impacting-lives-those-who-are-nowdacamented; see also Economic Benefits of Granting Deferred Action to Unauthorized Immigrants Brought to U.S. as Youth, AMERICAN IMMigRATION COUNCIL, (June 22, 2012), http://immigrationpolicy.org/just-facts/economic-benefitsgranting-deferred-action-unauthorized-immigrants-brought-us-youth.

107 Silva Mathema, Assessing the Economic Impacts of Granting Deferred Action Through D ACA and DAPA, CENTER FOR AMERICAN PROGRess (Apr. 2, 2015), https://www.americanprogress.org/issues/immigration/news/2015/04/02/110045/assessing-the-economic-impactsof-granting-deferred-action-through-daca-and-dapa/.

108 Goss, supra note 106. 
would not be legally allowed to work under the act. Moreover, JCT expects that wages for affected workers would decrease relative to their wages under current law as a result of their losing legal status under the act. That decrease in reported wages would cause decreases in receipts, most of which would be from Social Security taxes, which are categorized as off budget. ${ }^{109}$

On the law and policy, opponents might argue that the statute does not permit DHS to grant employment authorization to a person granted deferred action or another qualifying form of prosecutorial discretion. The Center for Immigration Studies, an organization that advocates restrictive immigration policy, has stated, "[t]he claim that 8 U.S.C. $\ 1324 \mathrm{a}(\mathrm{h})$ authorizes DHS to allow aliens to work is simply nuts." 110 Moreover, opponents might also argue that no person should receive permission to work until the U.S. labor market is tested. After all, many employment-based immigration categories require a qualifying relationship between a U.S. employer and the foreign national, efforts by the U.S. employer to recruit American workers, and certification from the U.S. Department of Labor. ${ }^{111}$ Contrast the employment-based immigration system to the employment authorization available to grantees of prosecutorial discretion where the individual can be employed anywhere and without any of these safeguards. This argument was at the heart of a lawsuit filed by SAVE Jobs USA in connection with a new regulation by DHS enabling certain spouses of temporary H1-B workers to be employed. ${ }^{112}$ The lawsuit alleged "DHS exceeds its authority by ignoring the statutory labor protections that must be applied to foreign labor. ... The H-4 Rule is in violation of 8 U.S.C. $\int S$ 1182(a)(5)(A), 1227(a)(1), that bar the admission of foreign labor unless the Department of Labor certifies, 'the employment of such alien will not adversely affect the wages and working conditions of workers in the United States similarly employed."'113

Apart from protecting the American workforce, opponents might also see an inconsistency with permitting individuals in a tenuous position like deferred action to apply for employment authorization and denying many other people with formal legal status employment opportunities under the current statutory framework. For example, neither foreign students who enter the United States on a temporary F-1 visa nor their spousal derivatives are qualified to work. ${ }^{114}$ Similarly, most derivative spouses of $\mathrm{H}-1 \mathrm{~B}$ workers are ineligible to apply for work authorization despite their residence in the United States with formal legal

\footnotetext{
${ }^{109}$ Letter from Douglas W. Elmendorf, Director of Congressional Budget Office to Honorable Thad Chochron, Chairman of the Committee on Appropriations (Jan. 29, 2015), https://www.cbo.gov/sites/default/files/114thcongress-2015-2016/costestimate/hr240.pdf; These findings are also consistent with the social science literature pertaining to the economic benefits of granting work authorization to deferred action beneficiaries. See e.g., Roberto G. Gonzales \& Angie M. Bautista-Chavez, Two Years and Counting: Assessing the Growing Power of DACA, AMERICAN IMMIGRATION COUNCI, June 16, 2014, http://www.immigrationpolicy.org/special-reports/two-years-and-countingassessing-growing-power-daca; see also TOM K. WONG, ANGELA S. GARCIA, MARISA ABRAJANO, DAVID FITZGERALD, Karthick Ramakrishnan, \& SALLy Le, Center For AmERican Progress, Undocumented No More: A NATIONWIDE ANALYSIS OF DEFERRED ACTION FOR CHILDHOOD ARRIVALS, OR DACA, (2013), http://cdn.americanprogress.org/wp-content/uploads/2013/09/DACAReportCC-2-1.pdf.

110 John Miano, Lawsuit Asks Whether the President Can Give Work. Authorization to Anyone He Wants, CENTER FOR IMMIGRATION STUDIES (Apr. 29, 2015), http://cis.org/miano/lawsuit-asks-whether-president-can-give-workauthorization-anyone.

111 See, e.g., 8 U.S.C. \$1182(a)(5)(A); see also U.S. Dep't of Labor, About Foreign Labor Certification, ,https://www.foreignlaborcert.doleta.gov/about.cfm (last updated May 19, 2014).

112 See Save Jobs USA v. U.S. Dep't of Homeland Sec., 105 F.Supp.3d 108 (D.D.C. 2015).

${ }^{113} \mathrm{Id}$. Alternatively, 85\% of the 13,000 commentators to the proposed rule supported the extension of employment authorization to a class of H-4 dependents. Employment Authorization for Certain H-4 Dependent Spouses, 80 FR 10,284 (Feb. 25, 2015) (to be codified at 8 C.F.R 214, 274a).

114 U.S. Citizenship and Immigration Services, Students and Employment, (last visited July 15, 2015), http://www.uscis.gov/working-united-states/students-and-exchange-visitors/students-and-employment. ("F-1 students may not work off-campus during the first academic year, but may accept on-campus employment subject to certain conditions and restrictions.").
} 
status. ${ }^{115}$ Why should a person released on an order of supervision or granted deferred action have the chance to work legally when these other categories offer no such opportunity to people living in the United States with legal status?

Those who oppose extending work authorization to grantees of prosecutorial discretion might also point to the long wait times faced to qualify for work authorization and lesser delays faced by qualifying individuals who apply for work based on prosecutorial discretion. For example, an asylum seeker may not apply for work authorization until at least 150 days from the date on which her application was filed.116 This asylum work authorization "clock" can also be stopped by officers and judges, enabling even longer wait times for genuine asylum seekers. ${ }^{117}$ Similarly, a victim of crime who applies for a U-visa may not apply for work authorization until her application is approved by USCIS. Currently, the wait times for a U-visa are more than one year. ${ }^{118}$ Finally, critics might argue that individuals may be tempted to color their claim or engage in fraud when making a request for prosecutorial discretion in order to receive permission to work. In fact, one theory that drove the old immigration agency, Immigration and Naturalization Service, to create a window of time before an asylum applicant can apply for employment authorization was to reduce fraud, while previously, an applicant could apply for asylum and work authorization simultaneously. Professor David Martin describes the pre-reform abuses: "Here then is the situation that fed on itself and bred abuse. As more and more undocumented aliens received speedy work authorization through this mechanism and yet never had to appear before an INS officer even to establish identity, much less to justify the asylum claim, the word spread about this magical path to genuine, legitimate [employment authorization documents]."119 The asylum changes were preceded by an impassioned debate by policymakers and advocates, some of whom argued that decoupling the asylum application from the employment authorization application would do more harm than good to the asylum seeker who is providing for herself and/or a family. ${ }^{120}$

The above concerns are reasonable to explore, but I am not persuaded that they trump the overarching benefits that flow from employing beneficiaries of prosecutorial discretion. Moreover, the inconsistencies and anomalies in immigration law and policy are pervasive and cannot be cured by eliminating work authorization for select PD grantees. Finally, my own view is that spouses of temporary workers like H-1B holders or students like F-1 students should be authorized to work for many of the economic reasons outlined in the foregoing paragraphs, and because it reduces the power and control that a principal spouse might have over the derivative (a topic well beyond the scope of this Article).

It is difficult to measure the degree to which economics should lead the conversation about whether work permits for prosecutorial discretion beneficiaries are good for society. Notably, there are other societal measures that may be worthy of discussion, but are beyond the scope of this Article. One study

115 Compare 8 C.F.R. $\int 274 a .12(c)$, Employment Authorization for Certain H-4 Dependent Spouses, 79 FR 26,886 (May 12, 2014) (to be codified at 8 C.F.R 214, 274a) (seeking to "extend the availability of employment authorization to certain H-4 dependent spouses of principal H-1B nonimmigrants”); U.S. Citizenship and Immigration Services, Employment Authorization for Certain H-4 Dependent Spouses, https://www.uscis.gov/working-united-states/temporaryworkers/employment-authorization-certain-h-4-dependent-spouses (last visited Mar. 2, 2016) (describing the limited categories of derivative spouses that are eligible for work authorization).

116 See, e.g., INA S 208(d)(2) (2015) (“An applicant who is not otherwise eligible for employment authorization shall not be granted such authorization prior to 180 days after the date of filing of the application for asylum.").

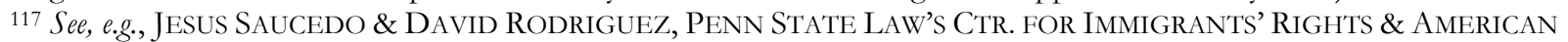
IMMigRATION COUNCIL LEGAL ACTION CTR., Up AgAinst THE ASYLUM ClOCK: FiXING THE BROKEN EMPLOYMENT Authorization AsYlum Clock 13 (2009), https://pennstatelaw.psu.edu/_file/Immigrants/Asylum_Clock_Paper.pdf.

118 U.S. Citizenship and Immigration Services, USCIS Processing Time Information, (last visited Feb. 2, 2016), https://egov.uscis.gov/cris/processTimesDisplayInit.do; see also U.S. Citizenship and Immigration Services, Victims of Criminal Activity: U Nonimmigrant Status, (Jan. 9, 2014), http:/ /www.uscis.gov/humanitarian/victims-human-traffickingother-crimes/victims-criminal-activity-u-nonimmigrant-status/victims-criminal-activity-u-nonimmigrant-status.

119 David A. Martin, Making Asylum Policy: The 1994 Reforms, 70 WASH. L. REV. 725, 735 (1995).

120 See Id. at 752-55; see also SAUCEDO supra note 117, at 7. 
demonstrates how a parent's undocumented status can affect the child: "The negative effects have been measured in educational achievement, cognitive development and emotional stability." 121 This same study highlights the benefits of providing a work permit to these parents:

With a work permit as provided for in the DAPA program, parents would have the opportunity to increase income, reduce poverty and thereby improve conditions for children. Indeed, wage growth among low-wage working parents can benefit children's academic and behavioral development by increasing parents' expectations for their children's school success and achievement. ${ }^{122}$

By removing the fear of deportation and increasing economic opportunity for the parent, a program like DAPA can be life changing and affect future generations. Such research must be part of the discourse surrounding the debate over work permits and prosecutorial discretion.

\section{A. Exploring Solutions}

Assuming one agrees with the premise that the statutory structure allows DHS to identify certain unauthorized individuals or classes for work authorization, finding a solution moving forward is a policy question rather than a legal one. Orders of supervision, parole, and deferred action are three forms of prosecutorial discretion that plainly identify a grantee as eligible to apply for work authorization. ${ }^{123}$ One policy question is whether work authorization should be granted for individuals who receive another type of prosecutorial discretion, such as a motion by ICE to administratively "close" a case that is ultimately approved by the immigration judge. As with a motion to close, and possible administrative closure by the immigration judge, there are several forms of prosecutorial discretion in immigration law for which no independent ground for work authorization is explicit. ${ }^{124}$ Below are some forms of prosecutorial discretion that do not explicitly provide an independent basis for work authorization:

- decision to refrain from issuing, serving, or filing a Notice to Appear;

- $\quad$ decision to cancel a Notice to Appear;

- decision to not stop, question, or arrest an individual;

- decision to not detain an individual or to release an individual already in detention;

- decision to join in a motion to close or terminate a case (with or without regard to whether such motion is ultimately granted by the immigration judge);

- decision to appeal a case;

- decision to stay removal in a case. ${ }^{125}$

\footnotetext{
121 Roberto Suro, Marcelo M. SuareZ-Orozco \& Stephanie L. Canizales, Tomás Rivera Policy Inst., REMOVING INSECURITY: HOW AMERICAN CHILDREN WILl BENEFIT FROM PRESIDENT OBAMA'S EXECUTIVE ACTION ON IMMIGRATION, GLOBALIZATION AND EDUCATION AT UCLA (2015), http://trpi.org/pdfs/research_report.pdf. ${ }^{122} \mathrm{Id}$.

${ }^{123}$ Even so, employers have not always accepted an employment authorization document as proof of eligibility. In one case, a noncitizen legally authorized to work in the United States brought a lawsuit against the Northwestern Mutual Life Insurance Company because the company had a policy of hiring only U.S. citizens or those with lawful permanent residence. See Juarez v. Nw. Mut. Life Ins. Co., 69 F.Supp.3d 364, 368 (S.D.N.Y. 2014).

124 The term "explicit" here means that the plain language of the statute or regulations identifies a particular prosecutorial discretion grant as a basis for applying for work authorization.

125 This list is adapted from the most recent prosecutorial discretion memo, but these factors have been featured in nearly every prosecutorial discretion guideline since 2000. Jeh Charles Johnson Memorandum, supra note 3.
} 
Possibly, using 8 U.S.C. $\int 1324(\mathrm{~h})(3)$, extending work authorization to individuals who benefit from one of the prosecutorial discretion forms listed above is a good policy. ${ }^{126}$ A narrower solution is to enable any person with a prosecutorial discretion grant to apply for work authorization so long as he can show "economic necessity" as is currently required for certain deferred action beneficiaries. This solution expands the pool of people who might be eligible to work but includes a limiting factor by requiring proof of economic necessity. Another possibility is to require any applicant seeking work authorization on the basis of a prosecutorial discretion grant to include documentation of a job offer and statement by a U.S. employer about his unsuccessful efforts to hire an American worker. This kind of statement would not be as labor intensive or costly as labor certification but would address the policy goals of protecting the American workforce. Yet another option is to limit work authorization to individuals who have received an affirmative form of prosecutorial discretion for a period of at least two years. USCIS could implement these policies by creating a regulation or guidance document with specified criteria required for work authorization.

\section{B. Political Challenges to Employment Authorization Applications}

In crafting a solution, the politics cannot be ignored. Possibly, the Administration may determine that it lacks the political space to create a broader policy that provides work authorization as an option for a greater pool of prosecutorial discretion grantees, especially in the wake of litigation. Even with the 2012 DACA program, critics opposed to work permits for young people in headlines:

- Work Permits for Young Immigrants Steal Jobs from Americans ${ }^{127}$

- Order for millions of blank work permits, green cards raising amnesty concerns ${ }^{128}$

- Obama Renews Work Permits for 520,000 Illegals'129

Now, the President's November programs on deferred action remain on hold because of litigation brought by Texas and twenty-five other states. In reading briefs and listening to the oral arguments, one has to wonder how much the Texas lawsuit has to do with the merit versus politics and the real opposition to a program that permits undocumented people to be employed. The controversy around work permits was well captured during oral arguments before the Fifth Circuit Court of Appeals on July 10 at which Judge Carolyn D. King asked Texas solicitor general Scott Keller, "[t]he state's position is, what you object to here, is the granting of work authorization to these individuals. You don't want them to have work authorization?"130 Judge King did not receive a clear response to her question but her question and Keller's lack of objection to her framing speaks volumes to the role employment authorization in the debate around the President's executive actions.

126 It may be legitimate to argue that the existing regulatory framework provides any person with a prosecutorial discretion grant to apply for work authorization-by illustrating for example, that 8 C.F.R. $\int 274.12(\mathrm{c})(14)$ reserved for those granted "deferred action" really means "any action that is deferred." However, this has not been how DHS has interpreted deferred action or the accompanying regulations that authorize work. To illustrate, deferred action is just one kind of action (among more than one dozen) listed in a medley of memoranda by the immigration agency on prosecutorial discretion. The author's view is that the agency's choice to limit work authorization to only qualifying individuals in a particular category of prosecutorial discretion (such as deferred action) is not unreasonable as a matter of law.

${ }_{127}$ Roy Beck, Work Permits for Young Immigrants Steal Jobs From Americans, U.S. NEWs \& WORLD PARTY, June 19, 2012, http://www.usnews.com/debate-club/is-obama-right-to-grant-young-illegal-immigrants-work-permits/work-permitsfor-young-immigrants-steal-jobs-from-americans.

128 Kenric Ward, Order for Millions of Blank Work Permits, Green Cards Raising Amnesty Concern, FoxNews, Oct. 21, 2014, http://www.foxnews.com/politics/2014/10/21/order-for-millions-blank-work-permits-green-cards-raising-amnestyconcerns/.

${ }^{129}$ Neil Munro, Obama Renews Work Permits for 520,000 Illegals, DAILYCALLER, June 7, 2014, http://dailycaller.com/2014/06/07/obama-renews-work-permits-for-520000-illegals/.

130 Recording of Oral Argument at 1:35:12, State of Texas, et al. v. USA, et al., No. 15-40238 (5th Cir. July 10, 2015), http://www.ca5.uscourts.gov/OralArgRecordings/15/15-40238_7-10-2015.mp3. 


\section{Operational Challenges to Employment Authorization Applications}

Co-existing with the political challenges are the operational challenges DHS and USCIS in particular may face in attempting to process deferred action requests and work permit applications in a timely manner. One illustration of this challenge can be found in the sheer number of work authorization applications coded as "pending" during 2014 in the data set analyzed for this Article. By regulation, USCIS is required to process most work authorization applications within a 90-day time period and, if failing to do so, issue "interim employment authorization" to affected applicants. ${ }^{131}$ And yet, many qualifying applicants have not received an interim work authorization as required by the regulation and in some cases, have been unable to work because they lack the evidence required by their employers to work in the United States. ${ }^{132}$ A review of the 2015 Annual Report by the DHS Citizenship and Immigration Services Ombudsman reveals that USCIS adjudicates the majority of employment authorization application within the 90-day timeframe, but for the thousands of individuals that face delays, this can mean a loss of employment to the applicant and negative consequences for the employer. ${ }^{133}$ The specific delay faced by DACA recipients was also reported by journalist David Noriega who obtained records from USCIS:

Thousands of undocumented immigrants who gained work permits as part of an Obama administration effort to shield young people from deportation are suddenly losing their ability to work legally as the federal government struggles to renew their authorizations on time. Exactly 11,028 young immigrants have had their Deferred Action for Childhood Arrivals (DACA) status and work permits expire in spite of having applied on time. ${ }^{134}$

The processing delays associated within the immigration system and DACA program specifically raise important questions about whether USCIS would have the resources and ability to adequately process work authorization applications for noncitizens granted any form of prosecutorial discretion.

\section{CONCLUSION}

This Article began with a description of the variations of prosecutorial discretion for which employment is authorized by statute and regulations, and clarified the relationship between prosecutorial discretion and work authorization. The Article highlighted data sets of select work authorization applications processed by USCIS on the basis of a grant of the following three forms of prosecutorial discretion: deferred action, order of supervision, and parole. The data reveals that the agency has a significant history of processing and granting work permits on the basis of prosecutorial discretion. At the same time, the data uncovers a spike in work authorization applications based on non-DACA deferred action in 2014 as well as a lower rate of approvals in 2014 in contrast to the overall average grant rate between 1990 and 2014. Finally, this Article showcases the economic arguments in favor of extending work authorization to prosecutorial

1318 C.F.R. \274a.13(d) ("USCIS will adjudicate the application within 90 days from the date of receipt of the application...Failure to complete the adjudication within 90 days will result in the grant of an employment authorization document for a period not to exceed 240 days.").

132 Complaint at 3, Northwest Immigrant Rights Project v. U.S. Citizenship and Immigration Services et al., 2015 WL 3392733 (W.D. Wash. 2015) (No. 2:15-cv-00813).

133 See Citizenship and Immigration Services Ombudsman, DeP’T of Homeland Security, AnNual Report 2015 48-50 (2015), http://www.dhs.gov/sites/default/files/publications/Final\%202015\%20CISOMB\%20Annual\%20Report_0.pdf; see also Shoba Sivaprasad Wadhia, Work. Authorization for Dreamers: $A$ Week of Wonders and Woes, ImMIGRATIONPROF BLOG (July 17, 2015), http://lawprofessors.typepad.com/immigration/2015/07/work-authorization-for-dreamers-a-week-ofwonders-and-woes-by-shoba-sivaprasad-wadhia.html.

134 David Noriega, Thousands of Dreamers are Losing Their Work Permits, BuZzFEED, Apr. 22, 2015, http://www.buzzfeed.com/davidnoriega/thousands-shielded-from-deportation-losing-work-permits. 
discretion recipients beyond that which is explicated in the regulations and the political landscape under which these policy questions should be raised.

Millions of unauthorized individuals are living in the United States today with a form of prosecutorial discretion because they are not a priority for enforcement and removal. But this discretion lacks the legitimacy of a comprehensive legislative solution and may (as we have seen with DAPA) result in a robust role for the courts and public skepticism about whether our government is following the rule of law. Many beneficiaries protected through prosecutorial discretion could be eligible for legal status and work authorization in the future if Congress finds a legislative solution. While the scope of this Article is focused on the relationship between work authorization and prosecutorial discretion, the importance of a legislative solution for the millions of people living in legal limbo remains critical. Even the best-looking policy for authorizing individuals with prosecutorial discretion for employment cannot replace the need for legislative reform.

\section{APPENDIX}

Table of Abbreviations

Administrative Procedure Act - APA

California Service Center - CSC

Code of Federal Regulations - CFR

Congressional Budget Office - CBO

Convention Against Torture - CAT

Customs and Border Protection - CBP

Deferred Action - DA

Deferred Action for Childhood Arrivals - DACA

Deferred Action for Parents of Americans and Lawful Permanent Residents - DAPA

Department of Homeland Security - DHS

Employment Authorization Document - EAD

Executive Office for Immigration Review - EOIR

Freedom of Information Act - FOIA

Immigration and Customs Enforcement - ICE

Immigration and Nationality Act - INA

Immigration and Naturalization Service - INS

Joint Committee on Taxation - JCT

National Benefits Center - MSC

Nebraska Service Center - NSC

Office of Legal Counsel - OLC

Order of Supervision - OSUP

Parole in Place - PIP

Post Order Custody Review - POCR

Prosecutorial Discretion - PD

Texas Service Center - TSC

United States Code - U.S.C.

United States Citizenship and Immigration Services - USCIS

Vermont Service Center - VSC

Violence Against Women Act - VAWA 